\title{
Insects Farmed for Food and Feed - Global Scale, Practices, and Policy
}

Abraham Rowe I 2020

$\underline{\text { Key Findings }}$

Introduction

Insect farming background information

Insect farming industries

The potential scale of insect farming

$\underline{\text { Wild insect collection }}$

Notes on the figures and terms

$\underline{\text { Insect outcomes }}$

Insect species

Average population

$\underline{\text { Insect farming totals }}$

Insect farming by species

Crickets

Mealworms

Black soldier flies

Other insects

Farming practices and conditions

Cricket farming practices and conditions

Mealworm farming practices

Black soldier fly farming practices

Other insect farming practices and conditions

Insect farming welfare concerns

Causes of death prior to processing

Slaughter methods

Transport methods

Life after the farm

Policy and regulations governing insect farming and consumption

United States and Canada 
Europe

$\underline{\text { Asia and Oceania }}$

Middle East, Africa, and Latin America

Areas for further research

What kind of experiences are most harmful for insects?

Is insect welfare obvious?

How likely is it that humans will start consuming insects more widely?

$\underline{\text { Appendix }}$

$\underline{\text { Models }}$

Methods

Areas of uncertainty in modeling insect farming

$\underline{\text { Notes on sources }}$

Acknowledgements

$\underline{\text { References }}$

$\underline{\text { References for scale estimates }}$

\section{Key Findings}

- Currently, 1 trillion to 1.2 trillion insects are raised on farms annually for food and animal feed.

- There are currently between 79 billion and 94 billion insects alive on farms globally on average on an average day.

- While it is unclear what welfare reforms might best improve the lives of insects on farms, it seems possible that standardized training on best practices, and potentially slaughter reform are promising ways to improve insect welfare on farms.

- The countries that farm the most insects in the world are Thailand, France, South Africa, China, Canada, and the United States.

- The industry is rapidly growing - millions of dollars have been invested into startups that are working to industrialize the industry, especially to produce insect alternatives to animal feed and fishmeal. This also means that the scale could increase by one or more orders of magnitude in the near future.

- Note that these estimates only include insects whose bodies are eaten in whole or powdered form for food and animal feed. They do not include insects farmed for

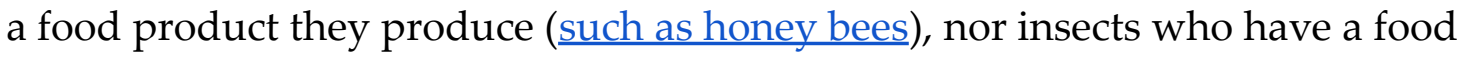


additive produced with a minor derivative of their bodies (such as cochineals). This research also does not cover wild insects collected for food or animal feed. Finally, this research does not cover annelids raised for fishing bait, though some of the insects sold live described in this report are likely used for fishing bait.

\begin{tabular}{|l|r|r|}
\hline Taxonomic group & $\begin{array}{r}\text { \# slaughtered, sold live, or dead } \\
\text { preprocessing annually }\end{array}$ & $\begin{array}{r}\text { Mean \# alive at any } \\
\text { time }\end{array}$ \\
\hline Crickets & $370 \mathrm{~B}$ to $430 \mathrm{~B}$ & $34 \mathrm{~B}$ to $41 \mathrm{~B}$ \\
\hline Mealworms & $290 \mathrm{~B}$ to $310 \mathrm{~B}$ & $25 \mathrm{~B}$ to $31 \mathrm{~B}$ \\
\hline Black Soldier Flies & $190 \mathrm{~B}$ to $300 \mathrm{~B}$ & $8.1 \mathrm{~B}$ to $16 \mathrm{~B}$ \\
\hline Other Insects & $120 \mathrm{~B}$ to $180 \mathrm{~B}$ & $4.8 \mathrm{~B}$ to $15 \mathrm{~B}$ \\
\hline All Insects & $\mathbf{1 T}$ to $1.2 \mathrm{~T}$ & $\mathbf{7 9 B}$ to $94 \mathrm{~B}$ \\
\hline
\end{tabular}

Fig. 1. Summary table of findings.

\section{Introduction}

This research covers the scale of insect farming globally, including the number of insects farmed in different regions, sold live or slaughtered, or killed during the production process and not otherwise sold. I break down these overall numbers into estimates by region and broad taxonomic group. I include estimates, by species and region, of the number of days on farms that insects experience. I also review the regulations governing insect farming, the practices found on insect farms, welfare concerns we might have for insects on farms, and potential promising interventions for insect advocates.

This research specifically covers insects whose bodies are eaten in whole or powdered form for food and animal feed. It does not review insects farmed for a food product they produce (such as honey bees), nor does it include insects who have a food additive produced with a minor derivative of their bodies (such as cochineals). This research also does not cover wild insects collected for food or animal feed. Finally, this research does not cover annelids raised for fishing bait, though some of the insects sold live described in this report are likely used for fishing bait.

This research does not touch on insect sentience or moral status. Generally, I am working under the assumption that all the insects mentioned are sentient in a morally 
relevant way, though since this paper focuses only on scale, the question of insect sentience and its moral relevance does not play a further role outside motivating the research. For further research into these questions, see Rethink Priorities' research into invertebrate welfare, and in particular, the analysis of fruit flies and ants, since they are insects currently impacted by farming.

\section{Insect farming background information}

Insects are currently raised as a food source for three groups of consumers - humans, companion animals, and farmed animals. Although insect consumption is a relatively novel phenomenon in the US and Europe, over two billion people eat insects weekly worldwide (Van Huis et al. 2013), and insect-eating has long been a major part of human culture. However, the majority of these insects are likely collected from the wild (see section "Wild insect collection").

Industrial insect farming is a relatively new practice, and so far has largely focused on feed production. There are some industrial-scale farms producing insects for human consumption in Asia, especially China and Thailand, but in the US, Europe, and Canada, major companies like Protix, Agriprotein, Beta-Hatch, and Ÿnsect are turning instead to raising insects for livestock and as a replacement for fishmeal. Indeed, Protix and Agriprotein have already built massive facilities for creating alternatives to the corn, soy, and fishmeal that livestock and fish are fed globally. If their project succeeds in producing a viable alternative to these products, we can expect the deaths caused by animal agriculture to multiply massively.

\section{Insect farming industries}

Insects are sold pre-slaughtered for human consumption, and sold both live and slaughtered for livestock and pet food.

\section{Feed for livestock}

Although insects have been fed live and dead as a supplement to livestock, particularly fish and birds, for decades (Van Huis et al. 2013), there is an emerging industry working to replace a significant amount of chicken feed and fish feed (particularly fishmeal) with insect products. This trend is driven by the possibility that farming insects to feed livestock could be cheaper than using soy, corn, or fishmeal. There are also some potential benefits to livestock health and welfare from introducing insects into their diets. And, companies have claimed that there may be environmental advantages to 
feeding livestock and fish insects instead of soy, corn, or fishmeal. For further information, see the April 2020 invertebrate welfare newsletter (Rowe 2020).

\section{Human food}

Insects raised for human consumption are generally sold either whole, as a powdered additive, or in premade products. Examples include whole crickets, cricket flour, or a nutritional bar that incorporates cricket flour. Relatedly, a secondary industry exists of producers of insect foods, where the producers purchase powder from a farmer and produce packaged foods. Very few insects are sold at restaurants or otherwise prepared for immediate eating in the US, Canada, and Europe. There are some legal hurdles to selling insects at restaurants, which are discussed later in this essay.

In Asia, Latin America, and Africa, insects are already a regular part of many peoples' diets (Van Huis et al. 2013). While a massive portion of these insects are collected wild, hundreds of billions of them are farmed. There are also many semi-agricultural practices used to encourage wild insect population growth for food purposes (Van Huis et al. 2013).

\section{Pet food}

Although there is some overlap between insects raised for pet food and insects raised for animal feed, there has long been a market for live and slaughtered insects for reptile and bird food. Many pet lizards are fed crickets, live or dead, and mealworms, for example, have been fed to backyard chickens as a dietary supplement for decades. More recently, insect farmers are producing foods for domesticated dogs and cats, primarily as a powdered protein additive.

\section{The potential scale of insect farming}

How many insects could be affected in the worst case scenarios for insects? The industry is currently excited about using insect meal as a replacement for fishmeal, which is a product made from ground wild-caught fish that is typically fed to fish and other animals (FAO 2016). A study funded by the Food and Agriculture Organization of the UN found that $25 \%$ to $100 \%$ of fishmeal could safely be replaced by insect meal (Makkar et al. 2014).

Global fishmeal production was 15.8 million tonnes in 2014 (FAO 2016). As an example, we might reasonably expect insect meal to replace $25 \%$ of global production, or 3.95 million tonnes. Agriprotein, one of the world's largest producers of insect meal, produces a fishmeal replacement made from black soldier fly larvae. A post-slaughter 
black soldier fly larva ground into insect meal weighs between $0.05 \mathrm{~g}$ and $0.1 \mathrm{~g}$. This suggests that if black soldier fly larvae replaced $25 \%$ of global fishmeal, it would cause somewhere between 40 trillion and 80 trillion deaths. Given that between 500 billion and 1.1 trillion fish are already killed for fishmeal (Mood \& Brooke 2019), replacing 25\% of the world's fishmeal with insects would cause 39 trillion to 79 trillion additional deaths, or 180 to 540 times as many deaths.

As a further demonstration of the potential scale of insect farming, Protix, a major producer, estimates that 30 million to 50 million tonnes of feedstocks could be replaced by insect protein, representing hundreds of trillions of additional insect lives and deaths (Protix 2020). Of course, these are the deaths required only to replace a fraction of global fishmeal production. The FAO study argued that soymeal fed to chickens could also be replaced. And there is the potential for an expansion of the number of insects already killed for human food. Across the board, animal advocates ought to be deeply concerned about the prospect of insects being raised for food.

\section{Wild insect collection}

This report does not evaluate wild insect collection. It seems that wild insects could be the majority of insects currently consumed, so this omission may be significant. For example, the FAO reports that 2 billion people regularly consume insects globally (Van Huis et al. 2013). Although consumption of insects varies throughout the year and from place to place, a conservative guess might be that the average insect eater eats around 20 insects a week. Considering examples given in the FAO report, this number seems reasonably low: in Kinshasa in the Democratic Republic of the Congo, 300g of mopane caterpillars (each weighing approximately $1 \mathrm{~g}$ ) are consumed weekly by the average household (Van Huis et al. 2013).

If 2 billion people consume 20 insects a week, then 2.08 trillion insects are consumed annually by humans. Since I estimated that at most 1.2 trillion insects are farmed, these numbers suggest that at least half of all insects killed for food are collected from the wild. Also, note that within the 1.2 trillion estimate, I found evidence to suggest that between 250 billion and 300 billion deaths occur during the farming process, which represent insect deaths that do not contribute to the food supply. So it seems reasonable to expect that more than half of insects consumed might be collected from the wild. 


\section{Notes on the figures and terms}

\section{Insect outcomes}

I list three types of insect outcomes in my estimate - insects sold slaughtered, insects sold live, and other deaths prior to processing. "Insects sold slaughtered" are sold after being killed by the farm, "insects sold live" are live (usually for pet, livestock, or fish feed), and "other deaths prior to processing" are deaths that occur on the farm prior to the insect growing fully (such as a cricket nymph dying from cannibalism).

Insects sold slaughtered

These are insects killed on the farm, and are typically dried and sold whole, or sold powdered. This is how the majority of farmed insects are processed.

Insects sold live

Insects are sold live as pet food (for reptiles, birds, and fish) or for livestock and farmed fish. This industry is surprisingly massive - I believe these insects for this market make up the majority of insects farmed in the US and Europe. They are impressively cheap.

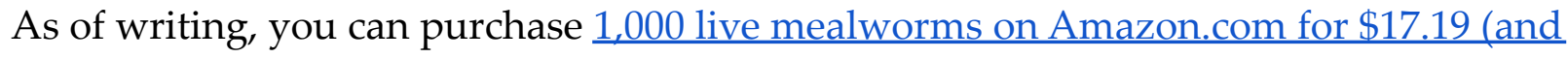
free shipping).

Other deaths prior to processing These figures represent insects who die prior to being slaughtered or sold. Insect farming often involves mass deaths, where a virus or bacteria will wipe out entire generations. Or, insects will die from cannibalism, starvation, or drowning early in life. Unless they are big enough to harvest, these insects are either thrown out or fed back to the insects on the farm as an additional source of chitin.

\section{Insect species}

I categorized farmed insects into 4 species groups, though unfortunately due to poor quality data, these categories are not perfectly consistent between regions.

\section{Crickets}

In the US and Europe, figures for crickets mostly refer to Acheta domesticus, the house cricket or pinhead cricket. In Asia, Latin America, and Africa, they also refer to some 
species of grasshoppers (though not all), such as chapulines in Latin America. In the US and Europe, grasshoppers are listed under "other."

\section{Mealworms}

Mealworms are the larvae of a species of darkling beetle. In Asia, Africa, and Latin America this figure likely includes many other beetle larvae, and possibly some caterpillars (larvae of moths or butterflies).

\section{Black soldier flies}

This category typically refers to the larvae of black soldier flies, which are historically relatively uncommon as an insect food, but have come to prominence especially as a promising fishmeal or animal feed alternative.

\section{Other}

This refers to all other insects and small terrestrial invertebrates that are farmed, from scorpions (not an insect) to caterpillars to beetle larvae to ants. Non-insect invertebrates might be included as the industry includes farmers who breed both insects and other invertebrates, and this is not typically differentiated by industry groups. Many insect farms use the word "insect" in a colloquial sense referring to a broad range of terrestrial invertebrates.

\section{Average population}

The average population estimate is the average number of the listed species alive on farms at any given time. These are found by taking the annual "days on farm" estimates from the model and dividing them by 365 . The total days on farm figures refer to how many days farmed insects live in total on farms. For example, if there are 5 insects on a farm for 10 days each, this corresponds to 50 total days experienced. This appears in the model as "days on farm." The average population figure is useful for direct comparison to similar estimates that have been made for farmed animals.

\section{Insect farming totals}

\begin{tabular}{|l|r|}
\hline Type & Number \\
\hline Total Insects Slaughtered & 560 billion to 680 billion \\
\hline Total Insects Sold Live & 180 billion to 230 billion \\
\hline Total Insects Dead Prior to & 250 billion to 300 billion \\
\hline
\end{tabular}




\begin{tabular}{|l|r|}
\hline Processing & \\
\hline Total Insects Farmed Annually & 1 trillion to 1.2 trillion \\
\hline Average Population at any time & $79 \mathrm{~B}$ to $94 \mathrm{~B}$ \\
\hline & \\
\hline Annual Production (tonnes) & \\
\hline US and Canada & 4,500 to 5,500 \\
\hline Europe & 6,000 to 6,500 \\
\hline Asia (including Pacific) & 26,000 to 28,000 \\
\hline Middle East + Africa & 19,000 to 21,000 \\
\hline Latin America (including Mexico) & 4,500 to 6,000 \\
\hline Total Production (tonnes) & 60,000 to 67,000 \\
\hline
\end{tabular}

Fig 2. Insect farming summary table - annual totals

\section{Insect farming by species}

\section{Crickets}

\begin{tabular}{|l|r|r|r|r|r|}
\hline $\begin{array}{l}\text { Crickets farmed } \\
\text { annually }\end{array}$ & Total farmed & \# slaughtered & \# sold live & \# other deaths & $\begin{array}{r}\text { Average } \\
\text { population }\end{array}$ \\
\hline Totals & $370 \mathrm{~B}$ to $430 \mathrm{~B}$ & $210 \mathrm{~B}$ to $250 \mathrm{~B}$ & $\mathbf{6 7 B}$ to $90 \mathrm{~B}$ & $81 \mathrm{~B}$ to $100 \mathrm{~B}$ & $34 \mathrm{~B}$ to $41 \mathrm{~B}$ \\
\hline US and Canada & $35 \mathrm{~B}$ to $45 \mathrm{~B}$ & $4.6 \mathrm{~B}$ to $11 \mathrm{~B}$ & $19 \mathrm{~B}$ to $28 \mathrm{~B}$ & $7.3 \mathrm{~B}$ to $11 \mathrm{~B}$ & $3.3 \mathrm{~B}$ to $4.4 \mathrm{~B}$ \\
\hline Europe & $34 \mathrm{~B}$ to $41 \mathrm{~B}$ & $4.3 \mathrm{~B}$ to $10 \mathrm{~B}$ & $18 \mathrm{~B}$ to $25 \mathrm{~B}$ & $7 \mathrm{~B}$ to $9.9 \mathrm{~B}$ & $3 \mathrm{~B}$ to $3.8 \mathrm{~B}$ \\
\hline Asia & $220 \mathrm{~B}$ to $270 \mathrm{~B}$ & $140 \mathrm{~B}$ to $180 \mathrm{~B}$ & $18 \mathrm{~B}$ to $38 \mathrm{~B}$ & $46 \mathrm{~B}$ to $64 \mathrm{~B}$ & $20 \mathrm{~B}$ to $26 \mathrm{~B}$ \\
\hline Middle East and Africa & $36 \mathrm{~B}$ to $44 \mathrm{~B}$ & $28 \mathrm{~B}$ to $31 \mathrm{~B}$ & $1.6 \mathrm{~B}$ to $4.7 \mathrm{~B}$ & $7.5 \mathrm{~B}$ to $11 \mathrm{~B}$ & $3.3 \mathrm{~B}$ to $4.1 \mathrm{~B}$ \\
\hline Latin America & $35 \mathrm{~B}$ to $49 \mathrm{~B}$ & $24 \mathrm{~B}$ to $35 \mathrm{~B}$ & $1.5 \mathrm{~B}$ to $5 \mathrm{~B}$ & $7.5 \mathrm{~B}$ to $12 \mathrm{~B}$ & $3.3 \mathrm{~B}$ to $4.7 \mathrm{~B}$ \\
\hline
\end{tabular}

Fig 3. Cricket farming summary table - annual totals 


\section{Mealworms}

\begin{tabular}{|l|r|r|r|r|r|}
\hline $\begin{array}{l}\text { Mealworms farmed } \\
\text { annually }\end{array}$ & Total farmed & \# slaughtered & \# sold live & \# other death & $\begin{array}{r}\text { Average } \\
\text { Population }\end{array}$ \\
\hline Totals & $290 \mathrm{~B}$ to $310 \mathrm{~B}$ & $\mathbf{1 5 0 \mathrm { B } \text { to } 1 7 0 \mathrm { B }}$ & $\mathbf{5 2 B}$ to $64 \mathrm{~B}$ & $\mathbf{7 6 B}$ to $90 \mathrm{~B}$ & $25 \mathrm{~B}$ to $30 \mathrm{~B}$ \\
\hline US and Canada & $26 \mathrm{~B}$ to $33 \mathrm{~B}$ & $2.1 \mathrm{~B}$ to $4.4 \mathrm{~B}$ & $16 \mathrm{~B}$ to $21 \mathrm{~B}$ & $6.8 \mathrm{~B}$ to $9.6 \mathrm{~B}$ & $3.9 \mathrm{~B}$ to $5.5 \mathrm{~B}$ \\
\hline Europe & $27 \mathrm{~B}$ to $31 \mathrm{~B}$ & $4.1 \mathrm{~B}$ to $6.3 \mathrm{~B}$ & $14 \mathrm{~B}$ to $17 \mathrm{~B}$ & $6.8 \mathrm{~B}$ to $9.1 \mathrm{~B}$ & $3.6 \mathrm{~B}$ to $4.9 \mathrm{~B}$ \\
\hline Asia & $\mathbf{1 3 0 B}$ to $140 \mathrm{~B}$ & $76 \mathrm{~B}$ to $90 \mathrm{~B}$ & $10 \mathrm{~B}$ to $20 \mathrm{~B}$ & $32 \mathrm{~B}$ to $43 \mathrm{~B}$ & $9 \mathrm{~B}$ to $13 \mathrm{~B}$ \\
\hline Middle East and Africa & $73 \mathrm{~B}$ to $85 \mathrm{~B}$ & $47 \mathrm{~B}$ to $54 \mathrm{~B}$ & $5.7 \mathrm{~B}$ to $8.7 \mathrm{~B}$ & $19 \mathrm{~B}$ to $25 \mathrm{~B}$ & $4.9 \mathrm{~B}$ to $7.4 \mathrm{~B}$ \\
\hline Latin America & $\mathbf{2 3 B}$ to $32 \mathrm{~B}$ & $15 \mathrm{~B}$ to $21 \mathrm{~B}$ & $1 \mathrm{~B}$ to $3.1 \mathrm{~B}$ & $6.1 \mathrm{~B}$ to $9.1 \mathrm{~B}$ & $1.6 \mathrm{~B}$ to $2.6 \mathrm{~B}$ \\
\hline
\end{tabular}

Fig 4. Mealworms farming summary table - annual totals

\section{Black soldier flies}

\begin{tabular}{|l|r|r|r|r|r|}
\hline $\begin{array}{l}\text { Black soldier flies } \\
\text { farmed annually }\end{array}$ & Total farmed & \# slaughtered & \# sold live & \# other deaths & $\begin{array}{r}\text { Average } \\
\text { population }\end{array}$ \\
\hline Totals & $200 \mathrm{~B}$ to $300 \mathrm{~B}$ & $\mathbf{1 2 0 B}$ to $220 \mathrm{~B}$ & $\mathbf{2 0 B}$ to $34 \mathrm{~B}$ & $40 \mathrm{~B}$ to $74 \mathrm{~B}$ & $8.2 \mathrm{~B}$ to $16 \mathrm{~B}$ \\
\hline US and Canada & $\mathbf{1 . 3 B}$ to $2.7 \mathrm{~B}$ & $120 \mathrm{M}$ to $340 \mathrm{M}$ & $850 \mathrm{M}$ to $1.7 \mathrm{~B}$ & $280 \mathrm{M}$ to $610 \mathrm{M}$ & $56 \mathrm{M}$ to $140 \mathrm{M}$ \\
\hline Europe & $\mathbf{2 0 B}$ to $42 \mathrm{~B}$ & $9.6 \mathrm{~B}$ to $21 \mathrm{~B}$ & $5.6 \mathrm{~B}$ to $13 \mathrm{~B}$ & $4.5 \mathrm{~B}$ to $9.9 \mathrm{~B}$ & $900 \mathrm{M}$ to $2.2 \mathrm{~B}$ \\
\hline Asia & $\mathbf{6 . 9 B}$ to $14 \mathrm{~B}$ & $2.4 \mathrm{~B}$ to $5.1 \mathrm{~B}$ & $3 \mathrm{~B}$ to $6.2 \mathrm{~B}$ & $1.5 \mathrm{~B}$ to $3.3 \mathrm{~B}$ & $300 \mathrm{M}$ to $750 \mathrm{M}$ \\
\hline Middle East and Africa & $\mathbf{1 3 0 B}$ to $260 \mathrm{~B}$ & $93 \mathrm{~B}$ to $190 \mathrm{~B}$ & $6.2 \mathrm{~B}$ to $17 \mathrm{~B}$ & $28 \mathrm{~B}$ to $61 \mathrm{~B}$ & $5.8 \mathrm{~B}$ to $13 \mathrm{~B}$ \\
\hline Latin America & $\mathbf{6 . 6 B}$ to $14 \mathrm{~B}$ & $4.5 \mathrm{~B}$ to $10 \mathrm{~B}$ & $340 \mathrm{M}$ to $1.3 \mathrm{~B}$ & $1.4 \mathrm{~B}$ to $3.3 \mathrm{~B}$ & $310 \mathrm{M}$ to $750 \mathrm{M}$ \\
\hline
\end{tabular}

Fig 5. Black soldier flies farming summary table - annual totals

\section{Other insects}

\begin{tabular}{|l|l|l|l|l|r|}
\hline $\begin{array}{l}\text { Other insects farmed } \\
\text { annually }\end{array}$ & Total farmed & \# slaughtered & \# sold live & \# other deaths & $\begin{array}{r}\text { Average } \\
\text { population }\end{array}$ \\
\hline
\end{tabular}




\begin{tabular}{|l|r|r|r|r|r|}
\hline Totals & $120 \mathrm{~B}$ to $180 \mathrm{~B}$ & $41 \mathrm{~B}$ to $83 \mathrm{~B}$ & $29 \mathrm{~B}$ to $66 \mathrm{~B}$ & $30 \mathrm{~B}$ to $63 \mathrm{~B}$ & $4.8 \mathrm{~B}$ to $15 \mathrm{~B}$ \\
\hline US and Canada & $6.3 \mathrm{~B}$ to $22 \mathrm{~B}$ & $880 \mathrm{M}$ to $3.9 \mathrm{~B}$ & $3.1 \mathrm{~B}$ to $11 \mathrm{~B}$ & $1.7 \mathrm{~B}$ to $6.7 \mathrm{~B}$ & $220 \mathrm{M}$ to $1.8 \mathrm{~B}$ \\
\hline Europe & $6 \mathrm{~B}$ to $20 \mathrm{~B}$ & $880 \mathrm{M}$ to $4 \mathrm{~B}$ & $3.2 \mathrm{~B}$ to $12 \mathrm{~B}$ & $1.8 \mathrm{~B}$ to $6.4 \mathrm{~B}$ & $230 \mathrm{M}$ to $1.7 \mathrm{~B}$ \\
\hline Asia & $39 \mathrm{~B}$ to $130 \mathrm{~B}$ & $13 \mathrm{~B}$ to $46 \mathrm{~B}$ & $13 \mathrm{~B}$ to $46 \mathrm{~B}$ & $11 \mathrm{~B}$ to $41 \mathrm{~B}$ & $1.5 \mathrm{~B}$ to $10 \mathrm{~B}$ \\
\hline Middle East and Africa & $20 \mathrm{~B}$ to $65 \mathrm{~B}$ & $12 \mathrm{~B}$ to $36 \mathrm{~B}$ & $1.7 \mathrm{~B}$ to $6.4 \mathrm{~B}$ & $5.4 \mathrm{~B}$ to $19 \mathrm{~B}$ & $790 \mathrm{M}$ to $5.5 \mathrm{~B}$ \\
\hline Latin America & $4.9 \mathrm{~B}$ to $16 \mathrm{~B}$ & $3 \mathrm{~B}$ to $10 \mathrm{~B}$ & $460 \mathrm{M}$ to $1.9 \mathrm{~B}$ & $1.4 \mathrm{~B}$ to $5.4 \mathrm{~B}$ & $190 \mathrm{M}$ to $1.5 \mathrm{~B}$ \\
\hline
\end{tabular}

Fig 6. Other insect farming summary table - annual totals

\section{Farming practices and conditions}

\section{Cricket farming practices and conditions}

Crickets are traditionally raised in plastic bins, with egg cartons or cardboard materials giving them space to move and lay eggs vertically, and with a layer of potting soil or similar substrate on the bottom. Crickets need highly humid environments to survive, so damp sponges are often placed inside these bins to regulate humidity (especially if the farm is in a dry environment). Because crickets are prone to drowning in pools of water, their water source is also often a damp sponge, according to an insect industry consultant. 


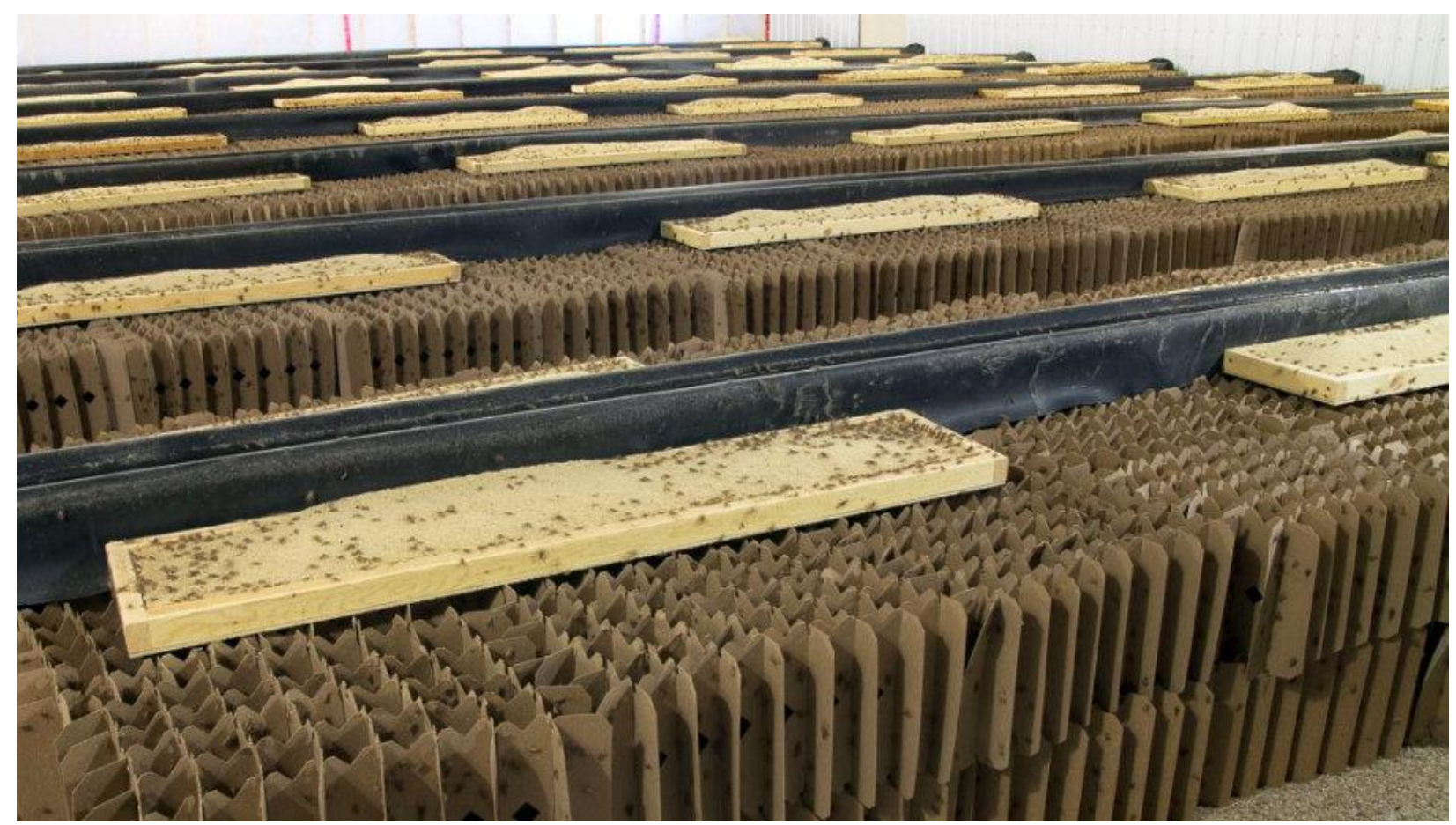

Fig. 7. Entomo Farms, the largest cricket farm in the world.

A female Acheta domesticus (commonly farmed in the US and Canada) cricket can lay around 3,000 eggs over the course of her life (8-10 weeks as an adult) (Clifford 1985), though industry sources say that typically, per cricket, you can expect around 100 eggs (Cricket Care 2020). I suspect the difference between these figures is how many eggs typically hatch, and the fact that female layers are often slaughtered prior to the end of their reproductive life. According to the producers I interviewed in the US and Canada, typically around 5,000 crickets live on each square foot of farming space, though information on animal numbers reported by survey participants was internally inconsistent, so I am uncertain if this figure is accurate.

Eggs hatch within two weeks, and nymph crickets break out of the eggs. These nymphs are integrated with a larger colony, though some are retained for further breeding in containers where conditions are conducive to breeding (higher heat and humidity).

In the US, Canada, and Europe, crickets are typically fed a combination of vegetables and chick starter feed (corn and soy) - some producers even list exactly what specific crickets were fed in a push for transparency (Craft Crickets 2020). My understanding is that diets are similar in Thailand and China, the other largest producers of crickets in the world, but I have no data on global cricket diets outside of conversations with the board of a US industry advocacy group. The Thai Agricultural Standards for cricket 
farms don't list specific requirements for feed outside of it being healthy for the crickets (Thai Bureau of Agricultural Commodity and Food Standards 2017). An unofficial translation of the detailed rules also provides no guidelines on feed, outside of it being within its expiration date (Bugsolutely 2017).

Surveying US and Canadian insect farms, I asked if there were differences in feed between crickets raised for human consumption and crickets raised for animal consumption. Most producers said no, though some who raised both said that they used GMO products for crickets raised for animals, and non-GMO products for crickets raised for humans. I suspect this makes no difference to the crickets. Additionally, no farms reported differences in feed used for crickets sold live or slaughtered. A 2005 study found that cricket yields would be largest if fed a diet of human refuse consisting of primarily fruit and vegetables, with some grains and meat (Collavo et al. 2005).

Crickets reach full size within seven to eight weeks, and are typically slaughtered or sold live immediately upon reaching that age. According to a US industry consultant, crickets are typically slaughtered in the US and Europe by freezing, though shredding and heating are also common. They are often freeze-dried to remove water, and sometimes freeze-dried live.

Currently, many cricket farmers use plastic bins and cardboard for their farms. Even the largest cricket farm in the world, Entomo Farms in Canada, appears to use simple cardboard towers for farming (Entonation 2018). However, automated systems that control humidity and temperature have become available for farmers over the last few years (

\section{Mealworm farming practices}

Mealworms are the larvae of mealworm beetles, a species of darkling beetle. However, many darkling and other beetle larvae are also bred for food - mealworms may just be the most common.

The first stage of mealworm farming is breeding darkling beetles. Unlike crickets, where the reproductive individuals are also the individuals that are killed and eaten, mealworm farmers also need a separate reproducitve colony to continue producing mealworms.. These beetles are kept in large bins, and maximum yield of eggs is achieved at around 0.84 beetles per square centimeter. Female beetles lay five to eight eggs a day, and about 300 over the course of a life (Andersen et al. 2017). 


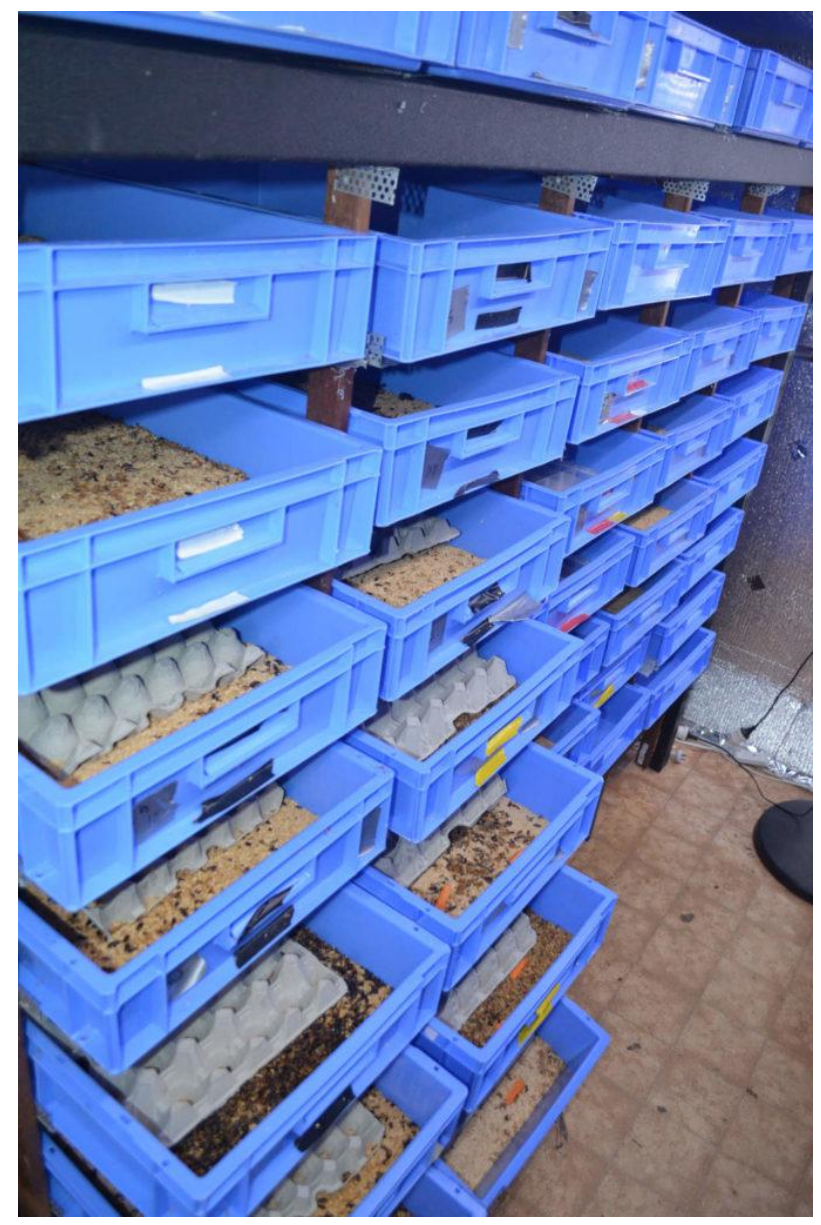

Fig. 8. The inside of a commercial mealworm farm.

After eggs hatch, producers focus on growing the larvae as quickly as possible. Temperature, humidity, feed, and stocking density all impact larval growth (Andersen et al. 2017). Once larvae reach full size (up to 170mg), they are separated from frass (insect waste) and bedding and food residues by using a sifting mesh (Andersen et al. 2017). They are then slaughtered in a variety of methods, though in the US and Europe, freezing or freeze-drying appear to be the most frequent. According to surveyed mealworm farmers, typical post-slaughter weight (after drying) is between 100mg and $110 \mathrm{mg}$. Some larvae are allowed to develop into beetles for further breeding.

Mealworms are fed bran from various cereals, vegetables, and fruit. Chicken feed is often used to feed mealworms, though it can be expensive. Larvae have a high feed conversion ratio $-2: 1$. Adult beetles have a lower conversion ratio and thus eat much less food per individual (Andersen et al. 2017). 
Larvae grow best at high temperatures, $86^{\circ} \mathrm{F}-90^{\circ} \mathrm{F}$, and at $50 \%$ to $70 \%$ relative humidity (Andersen et al. 2017).

According to a US industry group, mealworms are typically raised in large plastic bins that are insulated to keep heat generated by mealworms inside, increasing yield.

\section{Black soldier fly farming practices}

Black soldier flies originally came from Latin America, but are now established in most of the world, and are common in the US and Europe. Similarly to mealworms, black soldier fly producers must keep a breeding colony, as the primary food product produced is made from ground black soldier fly larvae (some literature will refer to them as maggots, which is a general term for fly larvae, but the industry seems to prefer the term black soldier fly larvae).

Adult black soldier flies are raised in netted boxes in relatively hot and humid conditions (above $73^{\circ} \mathrm{F}$ and $50 \%$ relative humidity). Water is provided (in shallow dishes to prevent drowning), and rotting food is also positioned at the bottom of the box. Adult black soldier flies lay eggs on available food, and are themselves typically not provided food by farmers. Typically, cereals, fruits, and vegetables are used. Food is kept moist, and mold is a frequent problem that is occasionally addressed by treating the food with antibiotics (Yang 2017). Black soldier flies typically lay eggs in cracks and crevices, so cardboard devices that provide appropriate conditions are provided (Bullock et al. 2013).

Eggs are moved from the breeding colony to a nursery bin, where they hatch after up to 10 days at a high temperature (up to $86^{\circ} \mathrm{F}$, Yang 2017).

The larvae can feed on a variety of foods, from cereals to fruits and vegetables to meat to animal waste (Yang 2017). Because of this, black soldier fly larvae might be an especially cheap insect to farm. They can be grown on much of the food waste produced by other human activity, but typically require some animal protein to thrive.

Larvae grow in large colonies, and thrive in very hot environments The colony core can reach $90^{\circ} \mathrm{F}-110^{\circ} \mathrm{F}$, though larvae will stop eating and die at higher temperatures (Yang 2017). Because they live buried in substrate (soil or mulch typically), the main factors leading to early deaths of larvae are temperatures getting higher than these limits, or poor ventilation of the substrate (Yang 2017). 
Black soldier fly larvae "self-harvest" in the sense that once they are fully grown, they will crawl out of the substrate and up the sides of a container. Producers take advantage of this by using harvesting compartments that the larvae fall into following this climb (Fisher and Romano 2020).

Black soldier fly larvae are frequently shredded and freeze-dried to produce a powdered product, unless they are sold as reptile food (Erens et al. 2012).

Common causes of preprocessing death on black soldier fly farms include parasitic wasps, mites, toxic fungi and mold growing on food, or viruses (Yang 2017).

\section{Other insect farming practices and conditions}

Dozens of other species of insects and terrestrial invertebrates are farmed for food, and practices vary widely from species to species. While I've not documented all practices here, many of the most common other species farmed, such as grasshoppers, various beetle larvae, and caterpillars (larval moths and butterflies) follow very similar procedures as the insects outlined above.

Much less information is available on some of the more unusual terrestrial arthropods farmed for food, such as scorpions.

\section{Insect farming welfare concerns}

Insect welfare may be hard to detect (see below: Areas for further research), so the focus of this section will be on common issues that either cause a premature death on farms and how insects are slaughtered. Some entomologists have claimed that captive insects are not particularly tolerant of "suboptimal conditions," meaning that if they are surviving they may be thriving. The evidence for this claim seems to primarily be that insects tend to die in captivity en masse when conditions change slightly (Boppré \& Vane-Wright 2019). If this claim is true, insect welfare advocates may want to focus on preprocessing causes of death and slaughter methods, which are outlined below.

One of few pieces of research exploring questions of animal welfare on insect farms, "A bug's life: large-scale insect rearing in relation to animal welfare," lists several areas of potential animal welfare concerns that were not shared by farmers (Erens et al. 2012). However, the paper frequently bases its animal welfare claims in what leads to greatest

yields of insects, and it is unclear how this correlates with animal welfare. Additionally, many of their claims are vague, and conflate welfare with preventing death. 
Industry documents on animal welfare are few and far between. The most relevant is the European industry lobby, International Platform of Insects for Food and Feed report on insect farming welfare. This document vaguely points to the five freedoms model of animal welfare, vaguely attempts to claim that insects might not feel pain, calls for more research to be conducted, and urges farmers to keep insects in high welfare conditions (IPIFF Animal Welfare).

There are likely other factors impacting insect welfare, such as diseases that injure but do not kill insects. When I spoke to farmers or industry experts about insect welfare, they consistently discussed early causes of death, and did not consider sub-lethal drivers of poor welfare. However, the one consistent non-death causing area of concern for farmers were pests that lived on or around crickets - especially fruit flies and mites. It is unclear what the impact of these pests is on crickets or farming.

Few insect farms mention animal welfare. Six Legs Farms in the UK prominently claims their crickets are high welfare, but did not respond to an email request for more information on this claim. Farms such as $\underline{\text { Ynsect }}$ and Entomo Farms also have brief mentions of insect wellbeing. However, there are some insights from Erens et al. 2012 into conditions on farms that might impact animal welfare:

\section{Light conditions}

In certain lighting conditions, some insects will enter a diapause, or a dormant state that can delay development. Additionally, insects experience circadian rhythm cycles, and lighting can affect how they enter and exit these cycles, which plausibly impacts welfare. Some producers raise black soldier flies in total darkness to reduce energy costs and maximize yield (Erens et al. 2012).

\section{Temperature}

Insects are extremely sensitive to temperature, and temperature can impact circadian rhythm cycles, insect breeding behavior, and insect metabolic rate and development. Again, it is unclear how these variations based on temperature impact welfare (Erens et al. 2012).

\section{Humidity}

Humidity variations can be fatal for insects. Incorrect humidities can also impact willingness to breed, and high humidity environments can lead to greater instances of fungal infections and other disease problems (Erens et al. 2012). 


\section{Rearing Density}

Insects raised at higher densities tend to be more susceptible to disease and for some species, more likely to cannibalize each other (Erens et al. 2012).

\section{Cleanliness}

Insects raised in unclean conditions, where proper sanitation measures are not taken, or in places where outside pathogens are brought in by HVAC systems or employees, are more likely to suffer from diseases (Erens et al. 2012).

\section{Feed}

Improper nutrition or contaminants in food can negatively impact insect development (Erens et al. 2012).

\section{Causes of death prior to processing}

From correspondence with and surveys of insect farmers in the US, Canada, and Europe, I believe that the most common causes of death prior to processing (live sale or slaughter) fall into five broad categories:

\section{Water-related deaths}

Insects are frequently reared in high humidity environments. According to a US insect industry consultant, deaths frequently occur on farms due to issues related to water, such as insects drowning in pools of water, insects consuming non-purified or treated water that has dissolved organic chemicals, insects consuming water that has been contaminated by frass or food, and a lack of water leading to dehydration.

\section{Cannibalism}

Insects frequently seek out chitin or exoskeleton. While a cricket, for example, might molt as many as eight times throughout its life, providing a source of chitin for itself, typically farms need to provide some supplementation, or insects will begin eating each other (Simpson et al. 2006). Farmers reported that insects, especially crickets, will eat other insects if not provided an outside source of chitin. Additionally, for crickets, an industry consultant reported that crickets will often eat each other when kept in dense populations, meaning that harvesting timing is often planned to take place before a mass die-off is caused by mutual cannibalism.

\section{Food contamination}

Since insects are frequently fed waste vegetables, or fed chicken feed kept in a high 
humidity environment, food frequently becomes moldy or soggy. In my interviews, respondents reported that such contamination can also be caused by infrequent changing of food, and frequently leads to death.

\section{Composition of diet}

Most insects eat a diet of chicken feed mixed with vegetables. If this mix doesn't meet nutritional requirements, they will often die. Additionally, one industry consultant mentioned that food from some sources can introduce diseases or viruses into populations.

\section{Disease}

Insects frequently die from viral infections, or parasites such as mites. Often, entire generations of insects will die at once, and industry experts say that stopping the spread of diseases within farms is difficult .

\section{Slaughter methods}

There is very little information on the prevalence of slaughter methods used for insects. The method of slaughter is to some extent shaped by the product being produced. For example, shredding is not appropriate for insects sold whole, since their bodies need to be intact. Producers that I interviewed reported freezing and shredding as the two most frequent methods of slaughter. Companies have also reported using freeze-drying, heating (via ovens or steaming), boiling, or asphyxiation (Erens et al. 2012).

Some methods that have been touted as more humane, such as freezing, seem unclear. The British and Irish Association of Zoos and Aquariums has released guidelines on invertebrate euthanasia, and suggest that freezing is one of the least ethical options (Pellett et al. 2013). This is because freezing may not provide muscle relaxation or an analgesic effect for insects. One recommended method for cricket and grasshopper slaughter is rendering the insects unconscious with carbon dioxide, followed by KCL injections (Pellet et al. 2013, Bennie et al. 2012). It's worth noting that this is not likely to be practical at a commercial scale. Unfortunately, most of the studies on humane invertebrate euthanasia look at species not closely related to insects farmed for food, such as spiders or lobsters. The BIAZA report also notes that detecting death in insects is somewhat difficult (Pellet et al. 2013). Recent literature reviews suggest that we don't have sufficient evidence to make claims about the relative humaneness of slaughter methods (Cooper 2011). The American Veterinary Medical Association guidelines for invertebrate euthanasia recommend against physical methods such as freezing or boiling, and also point to chemical injections as the most humane option for euthanizing 
invertebrates (AVMA 2020). However, freezing does appear to sedate shrimp (though not larger crustaceans), so it's possible these guidelines are not accurate (Weineck et al. 2018).

However, producers do provide another angle on slaughter not mentioned in the euthanasia literature. Protix, a major black soldier fly larvae producer, kills insects using shredding, which they claim takes a "split second" (Erens et al. 2012). If it is the case that shredding is incredibly quick, then it seems possible that this is preferable to "slower" methods like freezing or heating for overall welfare, and the duration of painful experience might be reduced. The $2013 \mathrm{FAO}$ report on insect consumption also suggests shredding or freezing as the most humane method for killing (Van Huis et al. 2013). Given the uncertainty around the humaneness of freezing, the limited evidence suggests that rapid shredding might be the least painful method for insect slaughter that is practical, as it seems unlikely that farms would adopt expensive chemical treatments.

\section{Transport methods}

For insects sold live (primarily for reptile and poultry food), transportation is an area of potential welfare concern. I did not collect data on transportation, so the conclusions presented in this section are more speculative. Josh's Frogs provides a live arrival guarantee on 3 day shipping, whereby the company provides a refund if the temperature stays within a specific range but the insects don't arrive live. Assuming that these ranges are a good proxy for temperatures that will kill insects during shipping, most insects seem to die at above $85^{\circ} \mathrm{F}$, and below $0^{\circ} \mathrm{F}$, though for some species commonly farmed, such as giant mealworms and superworms, the lower bound was more restrictive (up to $40^{\circ} \mathrm{F}$ ) (Josh's Frogs).

Another piece of evidence that temperature is the main consideration in the survival of insects during shipping is this discussion thread on ResearchGate, where researchers suggest using various insulated containers and heating devices for shipping live insects during winter. Insects also may be crushed by boxes, stuck in packing tape, or in the case of crickets, cannibalized if delivery is delayed. Based on Amazon.com and other sites, reviews suggest that not only do many insects regularly die during transportation, but that the common practice shipping method is to put insects into a container and send them through the mail. Companies might include instructions for keeping insects alive upon arrival. 


\section{Life after the farm}

A final area of welfare concern not covered in the estimates I've provided, or covered in the research, is the life of insects sold live after being raised and transported. Since most of these insects are raised for fish, livestock, or pet food, they will die during transportation, die during storage after transportation, be killed by the purchaser, or be eaten alive. I found no published information assessing the relative harms of these different ways of dying.

\section{Policy and regulations governing insect farming and consumption}

This is a brief outline of the legality of farming insects for human and animal consumption in various regions, and the current legislative and policy efforts that industry groups are undertaking.

There are limited resources available on the legality of insects as food and feed in many regions, and given the global prevalence of entomophagy, insects are likely permitted for human and animal consumption in many parts of the world. The most comprehensive review to date of laws governing insect feed are Sogari et al. 2019, "The potential role of insects as feed: a multi-perspective review," and the slightly outdated Lähteenmäki-Uutela et al. 2017, "Insects as food and deed: laws of the European Union, United States, Canada, Australia, and China".

\section{United States and Canada}

In the US, black soldier fly larvae has been approved by the Food and Drug Administration (FDA) as feed for salmonid fish, poultry, and pigs (Kelly 2020, Sogari et al. 2019). However, the FDA has not reviewed other insect products (Kelly 2020).

The FDA and an industry standard setter, the Association of American Feed Control Officials, are waiting on proponents of insect-based pet food to provide sufficient information to trigger an official "ingredient definition process" prior to insects being approved as an ingredient for pet food. Pet food manufacturers also may be required to conduct safety studies prior to approval (Kelly 2020). 
Insects raised for human consumption are approved in the US provided that the producer met standards set by the FDA, such as bacteriological tests and meeting labeling requirements. Importing insects for human consumption is also legal (Bugsolutely 2018).

In Canada, black soldier fly larvae are authorized for poultry feed and aquaculture, but other insects are not currently approved as animal feed (Sogari et al. 2019).

Pet foods containing insects do not need to be approved by a regulatory body in Canada, though they must not contain ingredients that are specifically considered dangerous (PFAC Industry Regulations 2015).

Insects are broadly approved for human consumption in Canada, though many have not been reviewed by the Bureau of Microbial Hazards, which could cause some insect foods to be banned in the future (Bugsolutely 2018).

\section{Europe}

In the European Union, after the Bovine Spongiform Encephalopathy (mad cow disease) outbreak in the early 2000s, animal-derived proteins were banned as animal feed. Currently, these laws prevent insects from being raised as poultry, pig, or cow feed. However whole insects are the exception to this ban. However, in July 2017, proteins derived from seven species of insects, including the major groups included in this report (black soldier flies, common house flies, yellow mealworms, lesser mealworms, house crickets, banded crickets, and field crickets were approved for aquaculture (European Union 2017).

This ruling has paved the way for the consideration of an exemption of the ban on animal-derived feeds for poultry. Currently the European Commission is considering a revision to feed ban rules to allow pork and insects to be fed to poultry (IPIFF EU Legislation).

Insects raised for human consumption are currently (2020) approved in the UK, the Netherlands, Belgium, Denmark and Finland. And, as of April 2020, the EU will likely soon approve some insect species as safe for human consumption, which will significantly increase the European market for insects (Boffey 2020). The EU also appears to be drafting hygiene regulations for insects raised for human consumption (European Union 2019). 
Insects have been approved for pet food in the EU, and dog food made from insects is available from companies like $\underline{\text { Yora }}$ (Kelly 2020).

\section{Asia and Oceania}

In China and South Korea, insects do not need authorization prior to being used for animal feed or human food, though there may be restrictions on their use as animal feed in North Korea (Sogari et al. 2019).

Thailand, the world's largest producer of crickets and grasshoppers, has released guidelines on farming practices for crickets (Thai Bureau of Agricultural Commodity and Food Standards 2017), but otherwise does not have regulations governing entomophagy or raising insects as animal feed (Bugsolutely 2018). Elsewhere in Southeast Asia, there generally do not seem to be laws preventing the consumption of insects by humans (Bugsolutely 2018).

In Australia and New Zealand, which share a food safety agency (called Food Standards Australia New Zealand or FSANZ), have reviewed some insect foods, such as crickets, superworms, and mealworms, and broadly have not put limits on the consumptions of these insects. Live insect imports for animal feed are not permitted (Insect Protein Association of Australia 2020).

\section{Middle East, Africa, and Latin America}

There has been less English language review of laws elsewhere in the world, but broadly, in many countries where insects have been consumed traditionally, such as Mexico, insects are permitted as food for both animals and humans (Lähteenmäki-Uutela et al. 2017).

\section{Areas for further research}

\section{What kind of experiences are most harmful for insects?}

Extremely little is known about insect sentience and insect welfare. Since responsiveness to a certain stimuli might vary widely from species to species, it seems unclear that single interventions to improve insect welfare will work on multiple taxa. One area for further research is identifying what kinds of stimuli common on insect farms are most painful for the species that are farmed, in order to prioritize interventions. Also, since many species of beetle worm, fly larvae, and other juvenile 
insects are farmed for food, further research is needed into how insect sentience varies throughout the lifecycle of insects.

\section{Is insect welfare obvious?}

A common view among insect farmers when discussing welfare is that it is obvious to them when insect welfare is high on their farms. Basically, there is a somewhat widespread belief that if insects are doing well, they survive, and if they are doing poorly, they die. This view is shared to some extent by the entomology community, where insects are described as being "far less tolerant of suboptimal conditions," than many vertebrates (Boppré \& Vane-Wright 2019). One reason for this is that besides occasional drownings, etc., insects will sometimes die en masse, suggesting that when conditions deviate from normal (when there are few deaths), there are suddenly many deaths.

It's unclear the extent to which this view is an accurate depiction of insect welfare on farms. It could be that within the confines of insect farms, the harms to insects tend to kill them. For terrestrial vertebrates, it seems like many animals that are farmed plausibly have low welfare, and yet the animals do not suffer high mortality rates - it is unclear if we ought to expect the same to be true of insects. It also seems possible that humans are just bad at casually assessing insect welfare, so farmers are missing important aspects of insect wellbeing.

However, if this claim is true, it might be good news for insect welfare advocates addressing early mortality might take care of many welfare concerns on farms.

To assess this, one area for further research is determining whether or not the experiences that tend to be most harmful to insects will also generally lead quickly to their deaths.

\section{How likely is it that humans will start consuming insects more widely?}

After conducting this review, it seems likely that this most concerning trend in the insect farming space is the production of insects for animal feed. However, there is some possibility that the five billion humans who don't regularly eat insects might start. Understanding whether or not this is likely could shape the priorities of insect advocates. If it is unlikely, then focusing on reducing current farming or preventing regulatory approval of insects raised for feed might be a more urgent intervention. Additionally, human consumption of insects likely trades off against consumption of 
animal products to some extent, while among insects raised for animal feed, only those replacing fishmeal trade off against the consumption of animal products. This suggests that the cost-effectiveness of reducing insects raised for human consumption could be lower than reducing similar numbers of insects raised for feed.

In terms of interest, Van Huis 2020 notes that academic interest in edible insects has grown significantly over the last several years. In particular, interest is growing in black soldier flies, which are especially prevalent on farms raising insects for animal feed. Taken with the growing interest in plant-based foods, which are another meat alternative perceived as more sustainable than terrestrial vertebrate meat, these suggest the risk of greater human consumption of insects to be relatively low.

\section{Appendix}

\section{Models}

\section{Fishmeal replacement model}

$\underline{\text { Global estimate totals }}$

US and Canada insect farming model

Europe insect farming model

$\underline{\text { Asia insect farming model }}$

Middle East and Africa insect farming model

Latin America insect farming model

\section{Methods}

To develop these estimates, I started with current production tonnage estimates that have been completed by Barclays, the International Platform for Insects as Food and Feed (IPIFF), and other researchers (Morrison \& Patel 2019, IPIFF 2019, Behre et al. 2018 , Connolly 2019, Dossey et al. 2016). I broke these figures into estimates for production by region and insect species using information from researchers and communications with an insect industry group (Shockley \& Dossey 2014; Erens et al. 2012; $\underline{\text { Morrison \& Patel }}$ 
2019; Feng et al. 2017; Hanboonsong 2018; Kipkoech et al. 2017; Melzer-Venturi 2015; Miech 2018; Van Huis 2003; Koeleman 2016; Sogari et al. 2019; Weigel 2016). While there are high quality data on species produced in Europe, the US, and Canada, the data available on production in Asia are slightly less good (there are precise figures for China and Thailand, but not other regions), and worse still for the Middle East, Africa, and Latin America. Most of the uncertainty in the model lies in how regional production is split between different species of insects. However, due to the relatively low variation in insect weight, this ends up not causing a high amount of variation in the final figures produced by my model.

From tonnage estimates by region and species, I took typical farmed insect weights to produce estimates of total individuals farmed (Heckmann et al. 2018; Andersen et al. 2017; Morales-Ramos et al. 2020; Von Hackewitz 2018; WAES 1994). Then, Using information from interviews and conversations with farmers and an industry consultant, I estimated the average preprocessing death rate on farms and the ratio of insects sold alive and dead by species group in each region.

I combined these figures to produce overall estimates of slaughter numbers, live sale numbers, preprocessing death numbers, days-on-farm, and average population estimates. Note that the model extremes might all add up to a lower or higher value than the totals. This is because the model represents a $90 \%$ subjective confidence interval, and certain scenarios fall outside of this. For example, it is much more likely that Latin America produces the maximum estimate for black soldier flies slaughtered AND Europe produces the median estimate than it is that both regions produce the maximum estimate. So, some values might fall outside the range predicted by the model.

\section{Areas of uncertainty in modeling insect farming}

While these figures represent best guesses, the data for Africa and Latin America are extremely poor in both quality and quantity, and the data for Asia are somewhat similarly limited. Therefore the uncertainty in my estimates for these regions for some types of insects tend to be larger.

I also was surprised that the result of this approach to modeling produced a relatively small range of potential outcomes in terms of numbers of insects farmed. This is only one method for estimating the global total of insects farmed for food, and is potentially a flawed one, but ultimately, given that there are relatively accurate data about total 
production, the final figures were primarily sensitive to that narrow production range, and thus produced a narrow estimate.

Additionally, I am uncertain about the accuracy of my estimated ratios between insects sold live and slaughtered in Africa, Asia, and Latin America. Information on these rates is very limited, and these figures represent my best guess.

Finally, I think it is possible but unlikely that some of the insects that are counted here as preprocessed deaths end up sold. For a variety of reasons, including that most deaths seem to occur either to large groups of insects at once due to virus or disease, leaving them unsellable, or when the insects are very young, I think these are likely accurate, but a conservative approach might be to remove them from the estimate, leaving a final figure of 850 billion to 900 billion insects killed by farming annually.

\section{Notes on sources}

A lot of this research is based on conversations and surveys I conducted within the insect farming space over the last year. I've spoken or collected data from the owners or employees of 30\% of farms in the US, and 10\% in Europe. I've also based this work on conversations with industry groups and consultants.

Generally, the insect farming space is currently extremely transparent. At almost no point in this process, from reaching out to farmers to asking for specific data on practices, was information withheld (except sales figures). Occasionally, farmers were not interested in sharing specific practices or production figures, but generally the industry groups and people I spoke to were very helpful and interested in the work.

\section{Acknowledgements}

This essay is a project of Rethink Priorities. It was written by Abraham Rowe. Thanks to Daniela Walhorn, Saulius Simcikas, David Moss, Jason Schukraft, Peter Hurford, Marcus Davis, and Michelle Graham for reviewing drafts of this this research and providing feedback. If you like our work, please consider subscribing to our newsletter. You can see all our work to date here. 


\section{A \\ RETHINK \\ PRIORITIES}

\section{References}

Andersen JL, Berggreen IE, Heckmann LH (2017) “Recommendations for breeding and holding of regular mealworms." trans. Jost S. Insect Group, Water and Environment, Danish Technological Institute.

AVMA (2020) "Guidelines for the euthanasia of animals: 2020 edition." American Veterinary Medical Association.

Bennie N, Loaring C, Bennie M, Trim S (2012) "An effective method for terrestrial arthropod euthanasia." Journal of Experimental Biology vol. 215: 4237-4241. doi: 10.1242/jeb.074997.

Boffey D (2020) "Edible insects set to be approved by EU in 'breakthrough moment'." The Guardian.

Boppré M \& Vane-Wright R (2019) “Welfare Dilemmas Created by Keeping Insects in Captivity." in The Welfare of Invertebrate Animals. Springer.

Bugsolutely (2017) "Good agricultural practices (GAP) for cricket farming." trans. Bugsolutely. Thai Agricultural Standard TAS 8202-2017.

Bugsolutely (2018) “Legal status of edible insects." Bugsolutely.

Bullock N, Chapin E. Evans A, Elder B, Givens M, Jeffay N, Pierce B, Robinson W (2013) "The black soldier fly how-to-guide." Capstone Project. UNC Chapel Hill Institute for the Environment.

Clifford CW (1985) "The biology of egg production in the house cricket, Acheta Domesticus L." Doctoral Disseration. Louisiana State University. Accessed from $<$ https://digitalcommons.lsu.edu/gradschool disstheses/4046/>. 
Collavo A, Glew R, Huang YS, \& Chuang LT (2005) “Housecricket smallscale farming." In Paoletti MG (ed.) Ecological Implications of Minilivestock. Potential of Insects, Rodents, Frogs and Snails. Enfield N.H.: Science Publishers.

Cooper JE (2011) "Anesthesia, Analgesia, and Euthanasia of Invertebrates." ILAR Journal, vol 50 (2) 196-204. doi: /10.1093/ilar.52.2.196.

Craft Crickets (2020) "Cricket diet." Craft Crickets. Accessed from $<$ http://www.craftcrickets.com/cricket-diet.html $>$.

Cricket Care (2020) "Cricket life cycle." Cricket Care. Accessed from $<$ https://cricketcare.org/life-cycle/>.

Entonation (2018) "Inside the largest edible cricket farm in the world." Entonation. Accessed from $<$ https://entonation.com/inside-the-largest-edible-cricket-farm-in-the-world/>.

Erens J, Es Van S, Haverkort F, Kapsomenou E, \& Luijben A (2012) “ A bug's life: large scale insect rearing in relation to animal welfare." Wageningen University and Research.

European Union (2017) “Commission Regulation 2017/893.” enacted 24 May 2017.

European Union (2019) "Specific hygiene rules for insects intended for human consumption."

FAO (2016) "The State of World Fisheries and Aquaculture 2016: Contributing to food security and nutrition for all." Food and Agriculture Organization of the United Nations.

Fisher H \& Romano N (2020) "Black soldier fly larval production in a stacked production system." Global Aquaculture Alliance.

Halloran A, Flore R, Vantomme P, Roos N (ed.) (2018) “Edible insects in sustainable food systems." Springer. doi: 10.1007/978-3-319-74011-9.

Insect Protein Association of Australia (2020) "Insects as food." Insect Protein Association of Australia. 
IPIFF (2017) "Position paper: the use of insect proteins as animal feeds." International Platform of Insects for Food and Feed.

IPIFF (2019) “Guide on good hygiene practices." International Platform of Insects for Food and Feed.

IPIFF (2020) “IPIFF's policy priorities towards 2025." International Platform of Insects for Food and Feed.

IPIFF. "Animal welfare in insect production." International Platform of Insects for Food and Feed.

IPIFF. “EU Legislation." International Platform of Insects for Food and Feed. Accessed from $<$ https://ipiff.org/insects-eu-legislation/>.

IPIFF Frass Report (2019) "Contribution Paper on the application of insect frass as fertilising product in agriculture." International Platform of Insects for Food and Feed.

Josh's Frogs. “Live Product Guarantees.” Josh's Frogs. Accessed from $<$ https://www.joshsfrogs.com/live-arrival-guarantee>.

Kelly R (2020) “There's a fly in my kibble! Insect-based pet food takes off." Veterinary Information Network News.

Lähteenmäki-Uutela A, Grmelová N, Hénault-Ethier L, Deschamps M, Vandenberg G, Zhao A, \& Zhang Y, Yang B, \& Nemane, V (2017) "Insects as food and feed: laws of the European Union, United States, Canada, Mexico, Australia, and China." European Food and Feed Law Review, 12(1), 22-36.

Makkar HPS, Tran G, Heuze V, Ankers P (2014) "State-of-the-art on use of insects as animal feed." Animal Feed Science and Technology, vol. 197, 1-33.

Melgar-Lelanne G, Hernandez-Alvarez AJ, \& Salinas-Castro A (2019) “Edible insects processing: traditional and innovative technologies." Comprehensive Reviews in Food Science and Food Safety. doi: 10.1111/1541-4337.12463.

Mood A \& Brooke P (2019) "Estimate of numbers of fishes used for reduction to fishmeal and fish oil, and other non-food purposes, each year." Fishcount.org.uk. 
$<\underline{\text { htp:} \text { //fishcount.org.uk/studydatascreens/2016/numbers-of-fish-caught-for-fishmeal201 }}$ 6.php>.

Pellet S, Pizzi R, Trim S, Bushell M, Clarke D, \& Wood J (2013) “BIAZA

Recommendations for Ethical Euthanasia of Invertebrates." BIAZA Terrestrial Invertebrate Working Group. Note that this resource isn't available online, but is available upon request.

PFAC Industry Regulations (2015) “Industry Regulations." Pet Food Association of Canada.

Protix (2020) "Protix Facts \& Figures." Protix. $<$ https://protix.eu/wp-content/uploads/Protix-Facts-ENG.pdf $>$.

Rolin K (2018) “New automation system design release.” Cowboy Cricket Farms. Accessed from $<$ https://cowboycrickets.com/blogs/news/new-automation-system-design-release $>$.

Rowe A (2020) “吕vertebrate Welfare - April 2020.” Invertebrate Welfare. $<$ https://www.invertebratewelfare.org/newsletter/2020-04>.

Sogari G, Amato M, Biasato I, Chiesa S, \& Gasco L (2019) “The potential role of insects as feed: A multi-perspective review." Animals (Basel) vol. 9(4): 119. doi:10.3390/ani9040119.

Thai Bureau of Agricultural Commodity and Food Standards (2017) "Good agricultural practices (GAP) for cricket farming." Thai Agricultural Standard TAS 8202-2017.

Van Huis 1 (2020) "Insects as food and feed, a new emerging agricultural sector: a review." Journal of Insects as Food and Feed vol 6(1): 27-44.

Van Huis A, Van Itterbeeck J, Klunder H, Mertens E, Halloran A, Muir G, and Vantomme P (2013) "Edible insects: future prospects for food and feed security." FAO Forestry Papers, vol. 171.

Yang S (2017) “Intensive black soldier fly farming." Symton Black Soldier Fly. 


\section{References for scale estimates}

Andersen JL, Berggreen IE, Heckmann LH (2017) “Recommendations for breeding and holding of regular mealworms." trans. Jost S. Insect Group, Water and Environment, Danish Technological Institute.

Behre E, Heukels B, Mayayo AM, Verschuur X (2018) “Insects as livestock feed: policy brief." UN Policy Analysis Branch, Division for Sustainable Development.

Connolly A (2019) “The buzz about insect protein.” Agritech Capital.

$<$ https://www.agritechcapital.com/ideas-you-can-use-food-beverage/2019/6/22/the-buzz -about-insect-protein>.

Dossey AT, Morales-Ramos JA, and Rojas MG, editors (2016) "Insects as Sustainable Food Ingredients: Production, Processing and Food Applications." Academic Press.

Erens J, Es Van S, Haverkort F, Kapsomenou E, \& Luijben A (2012) “ A bug's life: large scale insect rearing in relation to animal welfare." Wageningen University and Research.

Feng Y, Chen X, Zhao M, He Z (2017) “Edible insects in China: utilization and prospects." Insect Science, vol. 25 (2).

Hanboonsong Y, Tasanee J, \& Durst P (2013) “Six-legged livestock: edible insect farming, collecting, and marketing in Thailand." FAO Regional Office for Asia and the Pacific.

Heckmann, LH, Andersen JL, Gianotten N, Calis M, Fischer C, \& Calis H (2018) "Sustainable mealworm production for feed and food." Edible Insects in Sustainable Food Systems, 321-328.

IPIFF (2019) "The European insect sector today: challenges, opportunities and regulatory landscape." International Platform of Insects for Food and Feed.

Kipkoech C, Kinyuru JN, Imathiu S, \& Roos N (2017) “Use of house cricket to address food security in Kenya: nutrient and chitin composition of farmed crickets as influenced by age." African Journal of Agricultural Research, vol 12 (44) 3189-3197.

Koeleman E (2016) “Insect meal allowance expected in 2020." AllAboutFeed. 
Market Research Future (2019) "Insect protein market research report" $<$ https://www.marketresearchfuture.com/reports/insect-protein-market-6094>.

Melzer-Venturi G (2015) “PROteINSECT Agri Business Toolkit.” PROteINSECT.

Meticulous Research (2019) "Edible insects market by product type, application - global forecast to 2030."

$<$ https://www.meticulousresearch.com/product/edible-insects-market-forecast/>.

Miech P (2018) "Cricket farming: an alternative for producing food and feed in Cambodia." Doctoral Thesis. Swedish University of Agricultural Sciences.

Morales-Ramos JA, Rojas MG, Dossey AT, \& Berhow M (2020) “Self-selection of food ingredients and agricultural by-products by the house cricket, Acheta domesticus (Orthoptera: Gryllidae): A holistic approach to develop optimized diets." PLoS ONE 15(1): e0227400.

Morrison E \& Patel H (2019) “Insect protein: bitten by the bug." Barclays Investment Bank.

Shockley M \& Dossey AT (2014) “Insects for human consumption." Mass Production of Beneficial Organisms: Invertebrates and Entomopathogens, chapter 18, 617-652.

Sogari G, Amato M, Biasato I, Chiesa S, \& Gasco L (2019) "The potential role of insects as feed: a multi-perspective review." Animals, vol 9 (4), 119.

Van Huis A (2003) "Insects as food in Sub-Saharan Africa." International Journal of Tropical Insect Science, vol 23 (3): 163-185.

Von Hackewitz L (2018) "The house cricket Acheta domesticus, a potential source of protein for human consumption." Swedish University of Agricultural Sciences, Faculty of Natural Resources and Agricultural Sciences.

WAES (1994) “Mormon cricket.” Wyoming Agricultural Experiment Station Bulletin, vol 912.

Weigel T (2016) “Insects as food: market potential." Short course \& Workshop on Insects and Food and Feed, Kasetsart University. 
Weineck K, Ray AJ, Fleckenstein LJ, et al. (2018) “Physiological Changes as a Measure of Crustacean Welfare under Different Standardized Stunning Techniques: Cooling and Electroshock." Animals (Basel) 8(9): 158. doi:10.3390/ani8090158. 